gists who have worked in the Alaska Range to believe that that mountain chin had only slight topographic strength in the late T'ertiary; but that parts of it stood several thousand feet lower than now, is in entire accord with all the known facts. Analysis of the effects on climate which such a decrease in elevation would produce must be left to our brethren shilled in climatological research.

U. S. Geotogicat Survey,

Washington, D. C.

\title{
PLEISTOCENE AND RECENT TOPOGRAPHIC CHANGES IN THE PACIFIC COAST STATES
}

\section{JoHN P. BUWALDA}

Adrance Summary. - In comparison with the eastern half of North America, great topographic changes have occurred in the Pacific Coast States during the last three periods of geological time-the Pliocene. Pleistocene, and Recent. During these later periods of geological history the eastern mountains and plains have apparently suifered only relatively gentle upbowing or downwarping, but since the beginning of the Pliocene the western mountains and plateaus have not merely been uplifted thousands of feet but have been strongly folded and broken by faults. In the West, neighboring areas have mored in opposite directions. Some have gone up great distances and now form the high ranges; others have sunk and now either form the valleys into which the erosional detritus from the ranges is being in part deposited or they form estuaries or sounds if, lying near the Coast, they sank below sea-level.

While mountains existed in the west before the Pliocene, the great barriers of today have come into existence mainly during and since the beginning of that period. The duration of the Pleistocene and the Recent together was very much less than the Pliocene. The larger part of the growth of our present mountains was accomplished in the Pliocene, but very notable topographic changes occurred also in the Pleistocene and Recent.

It seems obvious that if the West Coast mountains have any effect on the climate of the interior of North America, marked changes in their altitude would result to at least some degree in changes in the climate they influence.

\section{GENERAL GEOGRAPHY OF THE PACIFIC COAST REGION}

As is well known, that part of the United States lying west of the Rocky Mountains is divisible topographically into four north-south belts. Skirting the shore of the Pacific lie the Coast Ranges, extending from southern California to the Canadian boundary. Their width is usually 
not over a few tens of miles and their height, excepting in three areas, is usually less than three thousand feet. To the east of the Coast Ranges lies a north-south line of valleys; these from Canada southward are the Puget Sound, Cowlitz, Willamette, Rogue, Sacramento-San Joaquin, Mohave Desert, and Salton Sink depressions. In Washington and Oregon the Cascades border this depression on the east; in California the Sierra Nevada occupy a corresponding position along most of the inland margin of the State. Extending eastward from the Cascades and Sierras is the desert region, usually known as the Great Basin, areally larger than the whole country to the west of it, and reaching to the base of the Rockies.

\section{MOVEMENTS ALONG CALIFORNIA COAST}

Pleistocene changes in relative level of land and sea along the California Coast are indicated by physiographic evidence and by position of Pliocene strata bearing marine fossils. At numerous places, notably south of San Francisco, at Santa Cruz, at San Pedro Hill near Los Angeles, and in the San Diego region, old strand-lines and marine terraces representing the ancient sea-floor, form steps from the present strand well up toward, or even attaining, the hill- or mountain-tops. They indicate intermittent uplift totalling not less than 1500 feet. The highest marine terraces are faint in their features, and it is possible that still higher ones originally existed but have been destroyed by erosion. They are not continuous at the same level along the Coast, however. Some stretches of the shore show evidence of submergence of at least some hundreds of feet. San Francisco Bay resulted from drowning through subsidence of a considerable stretch of the Coast. These uplifts and depressions were mainly Pleistocene in date. On the terraces are found the shells of organisms which lived on the ocean-floor before its emergence; they are largely living species. Where submergence has occurred it has been so late in geological time that the waves have modified the newly-established shores but little.

Pliocene marine sediments along the Coast bear out the evidence of the terraces, although the movements which tilted these strata were apparently often earlier than the terrace-forming uplifts. The uplifts and depressions were, however, largely post-Pliocene, and were of magnitudes comparable to those indicated by the terraces.

Less is known of the changes of level of the Washington and Oregon coasts. Terraces have been recognized, however, at many places and marine strata in a tilted position and of late geological age. It is clear that the northwest coast has undergone vertical movements comparable to those of the California Coast. The old strand-lines occur many hun- 
dreds of feet abore sea-level. Their Pleistocene age is attested by their preservation, even in the heary rainfall of that region, and by the fossils found on them.

\section{MOTEMENTS WITHIN THE COAST RANGES}

Three very precise surveys in the California Coast Ranges by the Coast and Geodetic Surrey, spaced approximately twenty-five years apart, have shown that peaks serving as triangulation points have moved in the intervals as much as twenty feet horizontally. These movements have probably been proceeding for a long time in the past and the aggregate displacements may be measured in miles or tens of miles. Vertical displacements of neighboring blocks with reference to each other are apparently not occurring at the present time so actively as horizontal shifting; but high scarps, particularly in southern California, attest to such displacements in very recent times. North of Pasadena and north of San Bernardino, and at other points, mountain-faces rise very steeply and boldly to heights of five to eight thousand feet above the adjoining plain. The slight degree of dissection by the erosional agencies indicates clearly that the uplifts occurred largely in Pleistocene and Recent time. Middle Pliocene strata cut by the fault of plane of breaking corroborate the late Pliocene and post-Pliocene dates of the morements. However, the peaks of these mountains had already reached approximately their present height in late Pleistocene time, for glaciation affected them. The evidence indicates, therefore, that most of the vertical mountainmaking movements occurred during later Pliocene time, and only a smaller part during the Pleistocene or Glacial period and the Recent period.

There is some reason to think that parts at least of the Coast Ranges may have been higher in late Pliocene time than they are now, and that hence during the Pleistocene they have been reduced somewhat in elevation. The folds raised in middle Pliocene time, of which only the roots remain now, would form high mountains, and it is possible that since about middle Pliocene time the general change in relief has been one of reduction of heights by erosion at a rate more rapid than the rate of uplift.

\section{PACIFIC VALLEY DEPRESSION}

While the Coast Ranges of California, Oregon, and Washington experienced uplift during the Pleistocene, the valleys lying to the east of them clearly were depressed. Puget Sound, in northwestern Washington, is a great river-valley system, with its branching arms, which was depressed and drowned by the sea. It probably sank not less than a thousand feet. The Willamette Valley has likewise been bowed down to some degree, 
in northwestern Oregon, and Pleistocene sediments spread thickly over its floor as a consequence.

In California, the Sacramento-San Joaquin Valley has been warped. downward while the adjoining mountains rose. Part of this depression doubtless occurred during the Pleistocene, although the larger part of it seems to antedate this period somewhat. And the same may be said for the Salton Sink depression; it is in part Pleistocene in date of origin.

\section{CASCADE MOUNTAINS AND SIERRA NEVADA}

With the possible exception of the Rocky Mountains, these two ranges form the most effective barrier in the western United States for influencing climate. Lying end to end, they extend from the Canadian boundary to southern Califormia, the south end of the Sierras terminating approximately at the southern margin of the belt of prevailing westerly winds.

The Cascades maintain a height of five to seven thousand feet practically throughout their length from Canada to northern California and the Sierras continue southward with about that elevation from northern California to central California, in the region about Lake Tahoe. From this point southward they rise from seven to about fourteen thousand feet in the Mt. Whitney region, south of which they descend again to three or four thousand feet.

The west slopes of these two ranges are heavily timbered and receive heavy precipitation. The east slopes are relatively dry and look out over the vast dry expanses known as the Great American Desert, the arid condition of which results mainly from the abstraction by these ranges of the moisture which the west winds from the Pacific would otherwise bear farther inland. The ranges create rain-shadow areas. The temperature conditions on the two sides of these ranges are likewise very different.

The geologic clate of uplift of these two ranges is probably about the same, if we may judge by the canyons cut in them since the beginning of their growth, and by stratigraphic evidence. They are probably both still rising, moreover, as attested by earthquakes. In 18 \% 2 a slip of several feet on a fault at the east base of the Sierras in Owens Valley was doubtless a detail of this upward movement. Lower Pliocene, and perhaps younger strata, have been disturbed along the bases of the ranges, so that it appears that the initiation of their latest elevation occurred in post-lower Pliocene time. Both ranges had, however, reached approximately their present height by the Glacial period, at least. by the latter part of it, for they show strongly the evidence of having borne large ice streams in their higher parts. Moraines found along their eastern base indicate that the Sierras probably stood at approximately their present height during the last two, and perhaps the last three, of the advances 
of the Pleistocene ice. The Cascales are likewise strongly glaciated. It is clear that the major part of the uplift of these ranges had been accomplished by middle Pleistocene time.

In comection with the effect of these ranges upon the climate of the country to the east, it is of interest to note that the level of maximum precipitation is about seren thousand feet on the west slope of the Sierras. This would apparently indicate that for each additional thousand feet increase in height of the mountains above the seven thousand feet level, the corresponding additional effect upon the climate to the enst would be less.

\section{GREAT BASIN PROVINOE}

The region between the Cascades and the Sierras on the west, and the Rockies on the east, lies in general lower than the western ranges bordering it, and it hence has no such marked effect upon the climate of regions to the east. But it is interesting to note that this immense clesert province, larger in area than the whole region lying west of it, is apparently still being actively deformed with resulting changes of level. One range in Nevada has been uplifted within historic times, with slipping on the fault bounding it to the extent of several feet. Bold fault-scarps in southeastern and northeastern Oregon, and occasional earthquakes in eastern Washington, indicate clearly that the growth of the separate mountain-masses lying within the Great American Desert is still in progress. But here again, as in the case of the Cascades and Sierras, the larger part of the movements which created the ranges appear to have occurred before the last glacial advances. The summit regions of a number of the ranges were vigorously glaciated. Clear evidence of post-glacial faulting and uplift is presented at a number of places, but the movements were not large in magnitude.

\section{CONCLUSION}

Evidence from physiography, structural geology, and paleontology combines to demonstrate that uplifts of hundreds of feet, and in some areas, probably thousands of leet, have occurred in our Pacific Coast mountain belts since the begimning of Pleistocene time. Depressions of hundreds of feet have occurred in some other localities. The movements are continuing today, possibly as actively and rapidly in many places as at any time in the past. This latter fact merely tends to emphasize the recency of many of the larger changes in level and topography. A large part of the changes in level had been accomplished before at least the last two dates of advance of the ice during the Pleistocene. 